\title{
Living as a Spiritual Virgin and Claiming Prophetic Authority: The Parallel Lives of Maria Petyt and Antoinette Bourignon
}

\author{
Mirjam de Baar
}

One of the most exciting things about doing historical research is discovering previously unknown manuscripts, particularly when they shed an entirely new or different light on familiar historical figures and raise new questions. This applies in particular to the Latin manuscript with autobiographical writings by Maria Petyt, which was recently discovered by Esther van de Vate in the Archive of the Carmelites in Rome. ${ }^{1}$

Until now, Maria Petyt has always been regarded on the basis of her known autobiographical writings as a mystic who withdrew from the world to devote herself to prayer and meditation. But an entirely different picture seems to emerge from the recently discovered Latin manuscript - a picture of a woman who took a very close interest in political affairs and adopted a position in disputes in the church politics of her day. The question is how these seemingly conflicting self-representations relate to one another and, following on from that, how Petyt, as a religiously inspired woman, tried to assume - or was given - authority. Was this a atypical case or does Petyt's conduct fit into the repertoires of religious behaviour of female contemporaries who, like her, laid claim to a right to speak on religious matters? To answer these questions, I shall summon up another seventeenth-century spiritual virgin - another mystic and author of religious and autobiographical writings - whose early life and work have a lot in common with Maria Petyt's but who made completely different choices later in her life. She is Antoinette Bourignon. Unlike Maria Petyt she would break up with the Roman Catholic Church as an institution and cross the dividing line between the various Christian denominations by founding an ecumenical congregation before the term existed. ${ }^{2}$

1 Vita venerabilis matris Mariae a Sta Teresia, Rome, Carm. Archive, Post III, 70, fol. 3or-49v, translated into English by Veronie Meeuwsen. See p. 119-239 of this volume.

2 On Bourignon's spiritual leadership see esp. de Baar (2004).

(C) MIRJAM DE BAAR, $2015 \mid$ DOI 10.1163/9789004291874_006

This is an open access chapter distributed under the terms of the Creative Commons AttributionNoncommercial 3.o Unported (CC-BY-NC 3.o) License. 


\section{The Self-Narratives of Maria Petyt and Antoinette Bourignon}

Maria Petyt and Antoinette Bourignon were contemporaries: Maria Petyt lived from 1623 to 1677 , Antoinette Bourignon was born in 1616 and died in 1680. Both left a spiritual autobiography that was published posthumously. Coincidentally, these works came out in the same year. Petyt's Het Leven was published in Gent in 1683 by Jan vanden Kerchove, in an edition edited by her spiritual mentor Michael of St. Augustine. ${ }^{3}$ La Vie de Dam.lle Antoinette Bourignon, edited by her spiritual son Pierre Poiret, was published by the Amsterdam booksellers Pieter Arentsz and Jan Rieuwertsz. ${ }^{4}$ Anyone who studies the biographies of Maria Petyt and Antoinette Bourignon in any sort of detail must immediately be struck by the number of parallels in their self-narratives.

Maria Petyt and Antoinette Bourignon were both born in the southern Flemish (now French) part of the then Southern Netherlands: Antoinette Bourignon in the city of Lille, and Maria Petyt forty kilometres away in Hazebrouck. ${ }^{5}$ The language boundary between the Flemish-speaking and Frenchspeaking regions of south Flanders ran precisely between the two places. Maria Petyt consequently grew up in a Flemish-speaking environment, although in her youth she spent some time in Lille and in Saint-Omer to learn French. ${ }^{6}$ Unsurprisingly, her written Flemish is laced with French words. Bourignon's native tongue was French, although she must have been familiar with Flemish to some extent. In her autobiography she tells that when she was a child her parents sent her to Ieper for ten months to learn Dutch. ${ }^{7}$ Maria Petyt and Antoinette Bourignon both dwell on their childhoods at length in their autobiographies, on the parental environment in which they grew up and their leanings towards a life dedicated to God. Put the two autobiographies side by side and you see two lives that followed more or less identical courses until the moment the women reached adulthood. They both grew up in a well-to-do merchant's

3 Het Leven van de Weerdighe Moeder Maria A S ${ }^{\text {ta }}$. Teresia, (alias) Petyt (1683), ed. Merlier (1976).

4 La Vie de Dam ${ }^{l l}$. Antoinette Bourignon (1683), translated into Dutch as Het Leven van Juffr. Antoinette Bourignon. Ten deelen by haar self, en ten deele by ymant anders van haar kennis (1683). This work includes Poiret's biography of Antoinette Bourignon and two autobiographies by herself: La Parole de Dieu, ou Sa Vie Intérieure, written in 1663, and La Vie Extérieure, written in 1668. On Poiret, a former Walloon minister, see Chevallier (1994).

5 Biographical details of Maria Petyt's life are taken from Merlier's edition of Het Leven van de Weerdighe Moeder Maria A S ${ }^{\text {ta }}$. Teresia, (alias) Petyt (1683). Biographical details of Antoinette Bourignon's life are taken from her own autobiographical writings, published in La Vie de Dam $^{\text {lle }}$. Antoinette Bourignon (1683).

6 Merlier ed. (1976) ch. viII, l. 20 = Petyt (1683) vol. 1, 11.

7 Bourignon (1668) 152-153. 
family where they lacked for nothing in material terms. Both became familiar at an early age with a faith pervaded by the spirit of the Counter Reformation. Lille, the prosperous textile city where Bourignon grew up and Petyt spent part of her childhood, was a bulwark of the Counter Reformation.

The Catholic offensive set in train after the Council of Trent went hand in hand with a re-landscaping of the public domain and with all sorts of new devotional practices. Between 1588 and 1667 the number of monastic foundations in Lille almost tripled. Towards the end of the sixteenth century, the Jesuits and the Capuchins - the two great militant orders of the Counter Reformation - founded new houses in the city. In their wake came other religious communities, which likewise focused primarily on prayer, instruction and evangelization. In the end seventeen new orders established themselves in the city, no fewer than twelve of them for women. The rise of all these new orders was accompanied by numerous new devotional practices, the construction of new Stations of the Cross, a revival of the Marian cult, countless processions and a run on relics, and by more intensive religious instruction, stronger visualization of key scenes in the life of Christ, more penitential sermons and so forth. ${ }^{8}$ The experiences and impressions described in Petyt's and Bourignon's autobiographies make abundantly clear the extent to which the new spiritual zeal bound up with the Counter Reformation left its mark on their view of faith and their perception of reality in their youth.

As they look back over their lives, both Petyt and Bourignon refer to the burning desire for 'the wilderness' they felt in childhood. ${ }^{9}$ The stories about the Desert Fathers, which they both knew well, must have been responsible for this at least in part. They both engaged in a battle with their parents to be allowed to pursue their spiritual ideal of a life cut off from the world and dedicated to God.

In 1636 Antoinette Bourignon ran away from home to escape a marriage her parents had arranged for her. In her spiritual autobiography written in 1663 she says that not long before this she had had a vision in which St. Augustine appeared to her and instructed her to restore his order. ${ }^{10}$ For Antoinette Bourignon this was the start of a long spiritual quest that would eventually bring her to a critical, independent attitude towards the church authorities. For her own part, she would rather have entered one of the strictest new orders, the dis-

\footnotetext{
$8 \operatorname{Lottin}(2013)$.

9 Merlier ed. (1976) ch. viII, l. 1-4 = Petyt (1683) vol. 1, 11. Bourignon (1663) 10; Bourignon (1668) 150 .

$10 \quad$ Bourignon (1663) 7-9. In La Vie Extérieure she does not refer to this vision.
} 
calced Carmelites, but her father refused to pay the dowry that was demanded. ${ }^{11}$

Maria Petyt did everything she could to persuade her parents of her deeprooted longing for the convent life and eventually managed to talk them into letting her go to the Augustinian convent of the canonesses regular in Gent recommended by her confessor. The French invasion of Flanders in 1643-44 and the looting it brought in its train meant that Maria Petyt had to postpone her plans for a year. As a result of the crisis, her father was unable to raise the required dowry and thought it was too dangerous for his daughter to travel all the way to distant Gent. ${ }^{12}$ The same incursion by the French army had personal consequences for Antoinette Bourignon, too. She had to leave the hermitage outside Lille city walls that she had moved into three years earlier because it was not safe to remain outside the city in time of war. ${ }^{13}$

Eventually both Maria Petyt and Antoinette Bourignon sought a way of life in which they could give their own independent interpretation of their ideal of a life devoted to God and centred on prayer and meditation. In the Catholic Southern Netherlands of the time, particularly in Brabant and Flanders, women's opportunities to find an appropriate form for this were legion. They could enter a regular order or opt for a life as a Beguine or a Spiritual Daughter. Monials (nuns) took vows for life (poverty, chastity and obedience). Beguines, in contrast, made temporary vows and did not take a vow of poverty at all. Spiritual Daughters generally did not take vows, but chose to remain unwed and lived as laywomen serving God outside the convent walls. ${ }^{14}$ Like the Beguines, they could retain their own possessions. The ways of life of Spiritual Daughters ranged from living alone or with a few other likeminded women, to coming together in a community. In practice these Spiritual Daughters often accepted a Rule, and placed themselves under the spiritual authority of their confessor. ${ }^{15}$ The Belgian Church historian M. De Vroede, who devoted a study to Spiritual Daughters in the Southern Netherlands, did not venture to estimate numbers, but did suggest that in the seventeenth-century, at least, this was a significant phenomenon encountered both in the towns and cities and out in the country. ${ }^{16}$

\footnotetext{
Bourignon (1663) 4-5.

Merlier ed. (1976) ch. XIX = Petyt (1683) vol. 1, 24ff.

Bourignon (1663) 63-65; Bourignon (1668) 181.

Monteiro (1996) 29-36.

On the fusion of these duties see Ranft (1994).

De Vroede (1994) (no references to Petyt).
} 
Unlike Maria Petyt, Antoinette Bourignon never joined a religious order. She often spent time in communities of spiritual virgins, but she never took vows. Occasionally she came under the authority of a spiritual director, but certainly not in the sort of formalized way that seems to have been the case with Maria Petyt. This would probably have led in practice to a focus on different forms of spirituality, but fundamentally they were both concerned with developing an inner spiritual life that would if possible lead to communion with God. They must in part have drawn upon the same spiritual sources. Direct and indirect references in their writings point to the work of, among others, Teresa of Avila, John of the Cross, Thomas à Kempis, Francis de Sales and Benedict of Canfield. ${ }^{17}$

Coincidentally, both Maria Petyt and Antoinette Bourignon ended up in Mechelen after an interlude in Gent. Petyt had indeed joined the Augustinian canonesses, but she had to leave the order during her novitiate because an eye condition prevented her from taking part in Mass as a choir nun. After a stay of five months at the Klein-Begijnhof in Gent, where she placed herself under the authority of a Carmelite as a novice of the Third Order, she moved in with another directee of this Carmelite. In her autobiography she describes the devotional practices and penances imposed upon her under his strict tutelage. When this Carmelite left Gent, she chose Michael of St. Augustine as her spiritual director and, when he became prior in Mechelen, she followed him after five years. In 1657 she and another sister moved into a house known as 'de Cluyse' - the hermitage - near the Carmelite church, and she lived there de facto in accordance with the first rule of the Carmelite order until her death. ${ }^{18}$ Some other likeminded women joined Maria Petyt in this house in Mechelen to share her way of life.

In 1653 Antoinette Bourignon became a regent and principal of a home for poor girls in Lille, where she submitted to the Rule of St. Augustine. Accusations of sorcery forced her to resign from her position in 1662, and she left Lille to seek justice from higher legal authorities. This took her first to Gent and then to Mechelen. In Gent Antoinette Bourignon lived for a while with a group of spiritual daughters. In 1663, six years after Maria Petyt, Antoinette Bourignon settled in Mechelen. For the first seven weeks she stayed in the GrootBegijnhof. After that she found a place with the Zwartzusters or Black Sisters.

During her time in Mechelen, Antoinette Bourignon's spiritual quest would result in a complete break with the Roman Catholic power structures. In 1667

17 Deblaere (1962) 128-164, 174-176; De Baar (2004) 205, 207, 222.

18 For her daily programme in these years see the contribution of Michel van Meerbeeck to this volume, p. 53-66. 
she left her homeland and settled in Amsterdam, the multi-confessional metropolis of the Northern Netherlands, with Christiaan de Cort, an Oratorian priest she had met in Mechelen and with whom she had become friends. Her life took a completely new course and her self-image and religious message changed dramatically. In Amsterdam Antoinette Bourignon broke through the boundaries of her religious environment. From 1669 she moved into the public sphere by publishing her writings in French and Dutch editions, later on also in German and Latin translations, so as to reach the widest possible readership. ${ }^{19}$ In part as a consequence, she claimed for herself an entirely new role as a spiritual leader for questing Christians.

Reviewing the biographies of Maria Petyt and Antoinette Bourignon, we can say that until 1667, the year Antoinette left the Southern Netherlands, there are remarkable similarities between their 'external' lives. The question is whether we can also discern clear parallels in the way each represented herself - and, if so, from what these resemblances derive.

\section{Teresa's Life as an Exemplar}

Peter Burke has pointed out the importance attached to modelling oneself on authorized examples in the Early Modern era when it came to self-representation in autobiographical texts. ${ }^{20}$ It is likely that Maria Petyt and Antoinette Bourignon chose to do this because their autobiographical writings served a very specific purpose. I shall come back to this shortly. This practice could go some way towards explaining why the life stories presented by Antoinette Bourignon and Maria Petyt are so remarkably similar.

Precisely when and why did Maria Petyt and Antoinette Bourignon commit the stories of their lives to paper? Without knowing what the other was doing, they wrote their spiritual autobiographies at much the same time, while they were living in the same town, Mechelen. According to the Belgian scholar Albert Deblaere, who investigated Maria Petyt's life and work thoroughly, she began writing her life story in 1662 and worked on it for several years. ${ }^{21}$ Bourignon wrote her Vie Intérieure in 1663 . Both Petyt and Bourignon wrote the stories of their lives on the instructions of a religious authority figure. In Petyt's case, it was her spiritual director and confessor, Michael of St. Augustine. He ordered her to write 'an account of her life' and at the same time to record the extraor-

\footnotetext{
19 See de Baar (2004), Appendix III (overview) and Appendix A (enumerative bibliography).

20 Burke (1997) 17-28.

$21 \quad$ Deblaere (1962) 31.
} 
dinary 'grace and divine influence she experienced by the mercy of God'. ${ }^{22}$ His intention was to use what she wrote to investigate whether Petyt was led by the spirit of God or whether she might be misled. In Bourignon's case it was the Vicar-General of the diocese of Mechelen, Aimé Coriache, who instructed her to write her life story. He was not her spiritual director, but Bourignon had asked him for his support in her legal proceedings against the magistrate in Lille after she had been discredited there because of a 'sorcery affair. ${ }^{23}$ Coriache wanted to know whether Bourignon really was sent by God, as she insisted, before he agreed to help her. Bourignon must have realized only too well that this request provided her with the opportunity to get her claims to authority validated. On 6 November 1663 she presented him with her spiritual autobiography, which bore the revealing title, La Parole de Dieu (The Word of God).

Earlier studies of Petyt focus on the influence of Teresa of Avila, her great exemplar, whose name she took as her second religious name during her time at the Beguine community in Gent. Deblaere, for instance, points to the correspondences in the description of the form and symptoms of the disease from which Petyt suffered right down to specific terms and images, and he goes on to draw attention to the comparable development that Petyt and Teresa underwent in their perception of Christ. Petyt also took her categorization of visionary experiences from Teresa. ${ }^{24}$

Teresa's autobiography (Libro de la Vida), which at that time was available in numerous Dutch editions, clearly did more than leave its mark on the substance of Maria Petyt's spiritual education. The published biography of the Spanish Carmelite nun, who was canonized in 1622, must also have served as a model and source of inspiration when Maria Petyt came to write the account of her own life. It is remarkable, for instance, to take just a small example, that Maria Petyt mentioned the pleasure she got from reading stories of chivalry just as Teresa of Avila had done. ${ }^{25}$

In an article on autobiographies by women in seventeenth-century Spain, the Spanish scholar Sonja Herpoel showed how Teresa's Libro de la Vida came to serve as a model for nuns. ${ }^{26}$ This exemplary function of Teresa's book seems not to have been confined to the Carmelite sisters and their area of influence. In terms of its form and content, Bourignon's La Parole de Dieu likewise has

\footnotetext{
22 Merlier ed. (1976) Introduction, 7-8.

23 For the accusations of sorcery see de Baar (2004) 74-78.

24 Deblaere (1962) 145-52. Cf. the contribution of Elisabeth Hense on the spirituality of Teresa of Avila and the Latin manuscript, p. 252-265.

25 Merlier ed. (1976) ch. XII, l. 17-19 = Petyt (1683) vol. 1, 16. Cf. Teresa of Avila (1990) vol. 1, 13.

26 Herpoel (1994) 42-57. Cf. Herpoel (1999).
} 
similarities to Teresa's spiritual autobiography, French editions of which were circulating in the seventeenth century. ${ }^{27}$

In writing the account of her life, Teresa of Avila had been influenced in turn by Augustine's Confessions, which is regarded as a paradigm for the genre of conversion literature in Western Christianity. At its heart is the destruction of old, sinful humanity and the rise of the new humanity reborn in Christ. In both Maria Petyt's and Antoinette Bourignon's work there are countless digressions about former levity and the worldly company in which they had lived. They can be described as topoi, but this does not detract from conversion. In both their autobiographies we also find the familiar topoi of the 'genre' of the vocation story: leaving parents, the specific motivation, the choice of a particular order or religious community, the opposition and the postponement of entering an order or community. In both, the subjection of one's own will to the will of God dominates the rest of their lives as they described them.

\section{Writing and being Written}

God and no one else, declared both Maria Petyt and Antoinette Bourignon, determined what they wrote. It was God, they said, who caused them to write through the inspiration of the Holy Spirit. They were only instruments. This claim to divine inspiration does not, however, alter the fact that we can identify countless places in their texts where the voice of God stops and that of the author herself begins. This raises the question as to whether two different components perhaps have to be distinguished in the writings of Maria Petyt and Antoinette Bourignon. I refer here, following the Belgian literary historian Karel Porteman, to the distinction between a receptive component - inspiration - and an active component - creativity, writing itself. In his discussion of Maria Petyt's work, Porteman tellingly summarizes the two components as 'writing and being written'. ${ }^{28}$

The term 'being written' contains within it the assignment of religious meaning promoted by female mystics. But in the same description we can also identify a sex-specific component that Porteman did not make explicit. In that sense, being written refers to one of the ways in which, until the Early Modern era, religious female writers justified their intervention in the dominant, male debate. What Maaike Meijer, an expert in cultural studies and Dutch literature, has observed more generally about women who write applied to these women

27 De Baar (2004) 207.

28 Porteman (1997) 285. Cf. Porteman and Smits-Veldt (2009) 829-832. 
as well. They had to subscribe to 'a cultural space where meanings are already laid down in a particular direction.29 Linda Anderson, who devoted a theoretical study to women's autobiographical writings, makes plain what this intervention implies: 'It is necessary to take into account the fact that the woman who attempts to write herself is engaged by the nature of the activity itself in re-writing the stories that already exist about her, since by seeking to publicize herself she is violating an important cultural construction of her femininity as passive or hidden. She is resisting or changing what is known about her'.30

Admittedly Anderson is referring to modern autobiographical writing in which reflection on the self is key, whereas Antoinette Bourignon's and Maria Petyt's autobiographical writings were primarily concerned with convincing the spiritual authority, on whose instructions the life stories were written, of their authenticity. And yet, the premise formulated here brings us back to the question as to how seventeenth-century semi-religious women like Maria Petyt and Antoinette Bourignon had to write to produce an effect - and do it in a period when the feminine mystical experience was treated with distrust. It was not for nothing that, from the Counter Reformation onwards, female mysticism was kept under control by the system of spiritual leadership. For religious female authors it consequently came down to using the right 'rhetorical strategies'. Alison Weber, for instance, demonstrates the way Teresa of Avila availed herself of the 'strategy of concession' or the 'strategy of humility'. ${ }^{31} \mathrm{We}-$ ber argues that using rhetorical strategies like these allowed Teresa to achieve her goals without disturbing the existing order. In the cases of Maria Petyt and Antoinette Bourignon, their credibility stood or fell by the extent to which they were able to persuade the reader of the message that God poured into their 'soul'. They had to find a convincing way of putting this in writing - but this was an act of human creativity that they could not lay claim to as such.

Regardless of whether Antoinette Bourignon and Maria Petyt were or were not convinced that they were inspired by higher powers and that it was not they, but God, who wielded their pens, putting this conviction into writing may have strengthened their prophetic identity. It could at the same time have reinforced their self-confidence in coming out with the divine truths that they were to interpret. From the previously unknown Latin manuscript of Maria Petyt's work, it would, after all, appear that, like Bourignon, she was credited with prophetic gifts.

\footnotetext{
$29 \quad$ Meijer (1996) 38.

$30 \quad$ Anderson (1986) 59.

$31 \quad$ Weber (1990) 50-64.
} 


\section{Prophetic Gifts}

Maria Petyt communicated her prophecies in her letters to Michael of St. Augustine, whom she explicitly asked to keep secret for as long as she would live. ${ }^{32}$ In the letters written between November 1672 and July 1673 she overtly demonstrated how she inwardly absorbed herself in the wars of Louis XIV empathizing with his victories and defeats. ${ }^{33}$ Maria Petyt even linked her spiritual credibility to the outcome of the French king's military fortunes which she prophesied. She also wrote to her confessor how in her prayers and visions she dealt with the conflict with Jansenism, which struck at the unity the Roman Catholic Church in these years.

Maria Petyt's engagement with political and ecclesiastical events may at first sight seem odd, but, as we will see from Antoinette Bourignon's example, a life of prayer and meditation dedicated to God and a strong involvement with the world were not mutually exclusive. It is inherent in the prophetic self-image that a prophet or prophetess who regards himself or herself as an instrument chosen by God is driven to convey the message to the outside world. The fact that this outside world was, in certain circumstances, extraordinarily receptive to messages interpreted by female prophets is evidenced by the response that Antoinette Bourignon provoked between 1663 and 1667 in the circles of Jansenist oriented clergy. While she was in Gent and Mechelen, Antoinette Bourignon met a number of clerics with Jansenist sympathies. ${ }^{34}$ As well as Aimé Coriache, there were Christiaan de Cort, Pierre Noels and Ignace Gillemans. Noels was an Augustinian priest, who had been Cornelis Jansen's secretary when he was Bishop of Ieper. Bourignon engaged in long conversations with him, about divine grace, about St. Augustine's ideas on it and about his conflict with Pelagius. On Noels' advice, it seems, she went to hear sermons by anti-Jansenists in Mechelen. Thanks to him she must have been able to build up a clear idea of the theological controversy that was causing considerable dissension among the clergy in Mechelen, too.

Antoinette Bourignon also conducted intense discussions, which she called 'conferences', with her other clerical friends. At these conferences she spoke freely about 'the miracles that God had performed in and through her, and

32 English translation of the Latin manuscript, The life of the venerable Maria of Saint Teresa 3or.

33 For Maria Petyt's preference for the French king see Veronie Meeuwsen's contribution to this volume, p. 240-251.

34 On Bourignon's involvement in the conflict between Jansenists and Jesuits between 1662 and 1667 see de Baar (2004) 82-94. 
those that He intends to do through her in the future'. The consideration with which her listeners responded to what Antoinette Bourignon herself regarded as her divine message must have strengthened her image of herself as a prophet. One of them, De Cort, wrote down the answers Bourignon gave to his questions about the Church, the creed, the monastic life and the gospel under the title La Lumière du Monde - the Light of the World. The conferences with her clerical friends inspired Antoinette Bourignon to write a series of treatises on divine grace, free will, preaching and devotions, confession, penitence, the Eucharist, prayer, discernment of spirits and so on. These pieces circulated in manuscript form among her clerical friends, who copied them for their own use.

It emerges from Antoinette Bourignon's correspondence that the circle of Jansenist clerics with whom she was in touch from 1663 onwards were not simply receptive to her 'feelings', but actively encouraged her to express them. They even urged her to go to Leuven and share her view of the downfall and destruction of the Church with the academics at the university there. We may conclude from this that Antoinette Bourignon had successfully assimilated the ideas of her Jansenist-sympathizer friends. At the same time, as a layperson and a woman she remained an outsider - an outsider, what's more, who was interested not so much in questions of doctrine as in religious practice. The fact that Antoinette Bourignon nonetheless was accorded theological authority suggests, rather, that she was able to make the best and most convincing use of the 'room to speak' that opened up in and through the clash between two conflicting representations of free will and divine grace. She even managed to steer her own course. For instance, while she took a firm position against penitence purely for fear of punishment (attritio) and emphasized the need for true, perfect repentance (contritio), at the same time she rejected the Jansenists' strict doctrine of grace, which ruled that a person might only approach God in fear. In Antoinette Bourignon's view everyone could in principle be saved, thanks to a special act of grace, by following Christ's example and turning back to God. ${ }^{35}$

\section{In Conclusion}

When I studied the historiography on Maria Petyt while I was preparing this contribution, it struck me how strongly she was embedded in a diachronic mystical tradition that goes back on the one hand to Flemish predecessors like 
Ruusbroec and Hadewych, and is inspired on the other by the Spanish mysticism of Teresa of Avila and John of the Cross. This embedding process was, of course, already set in train by Petyt's spiritual director, Michael of St. Augustine, who in selecting and publishing her writings had primarily an edifying goal in view. He presented Petyt, as emerges from his foreword to the reader, first and foremost as a model of virtue who deserved emulation. At the same time he endeavoured to silence any criticism of Petyt's work by contemporaries by propounding, contextualizing and empowering her bridal mysticism. ${ }^{36}$ It is thanks in part to his intervention that Petyt has come to be regarded above all as a mystical writer.

I have demonstrated in this article that a broader contextual and comparative approach to Maria Petyt sheds light on new patterns and parallels that can be important to a better understanding of her life and work. Now that we know that the writings edited by Michael of St. Augustine do not contain Petyt's full works and that the newly discovered manuscript in Rome paints a different picture of her from the one that emerges from her works published in the seventeenth century, it would seem to justify the conclusion that 'mystic' is too narrow a classification. Maria Petyt appears, rather, to have presented herself as a 'prophetess'. The example of her contemporary, Antoinette Bourignon, shows that a spiritual virgin focused wholly on God or Christ in seventeenthcentury Mechelen could certainly claim that role for herself.

From the recently discovered manuscript in Rome, it appears that Maria Petyt, too, took part in the dispute between the Jansenists and the Jesuits. Unlike Antoinette Bourignon she sided with the anti-Jansenists by disqualifying Jansenism as heresy. Was she in a similar way like Bourignon in contact with a network of anti-Jansenist-oriented clerics? Did she, like Bourignon, engage in so-called conferences, or was she involved in the theological arguments in some other way - through correspondence, perhaps? And finally, one could wonder whether Petyt and Bourignon may have regarded one another as competitors. Given the parallels between their lives and the small community in a seventeenth-century town like Mechelen, one would, after all, expect that at some point their paths must have crossed. However, there is nothing in their autobiographical writings to suggest that they were in touch either directly or indirectly. Is it possible that they 'cut each other dead' in their work, or did Maria Petyt only come to the fore after Antoinette Bourignon had left Mechelen in 1667 ?

It is typical of figures who present themselves as prophets or prophetesses that at a certain point they profess to be God's sole instrument chosen

36 Deblaere (1962) 15-22; Merlier ed. (1976) Introduction, 5-12. 
to proclaim His message to the world. ${ }^{37}$ This claim of exclusivity in no way implies singularity, however, as the large number of prophets and prophetesses who made their voices heard in the liberal Amsterdam of the seventeenth century testifies. What is surprising, though, is that in the seventeenth-century city of Mechelen at around the same time two spiritual virgins should appear on the scene and present themselves as prophetesses. It is not so much the fact that they were women that is remarkable. It was, after all, as Bourignon's male friends stated explicitly, specifically to women that prophetic authority could be given in a certain context. ${ }^{38}$ No, the surprising thing is that it has taken so many centuries for the intervention of a second religious or semi-religious female in a debate on a fundamental theological issue otherwise conducted by men to come to light. This has opened up new points of reference for further research on both Maria Petyt and Antoinette Bourignon, who besides siding with opposing Church parties seemed to have had much in common. Whether they also shared similar ideas on e.g. spiritual motherhood and on 'the discernment of spirits' remains to be investigated.

Further comparative research into their theological ideas, self-image and self-representation may not only contribute to a better understanding of both Mary Petyt's and Antoinette Bourignon's writings but also deepen our insight in the cultural context that nourished these spiritual virgins and within which they could make their voices heard.

Mirjam de Baar is Professor of Cultural History of Early Modern Christianity at the University of Groningen. Her current research focuses on the performance of male and female prophets in the Dutch Republic, their communication strategies and their involvement in international networks of religious dissenters in Early Modern Europe. She has published extensively on women and religion in the seventeenth century. mirjam.de.baar@rug.nl

\section{Bibliography}

Anderson, L. 1986. At the Threshold of the Self: Women and Autobiography. In M. Monteith ed., Women's Writing. A Challenge to Theory. Brighton. 54-71.

Baar, M. de. 2004. 'Ik moet spreken'. Het spiritueel leiderschap van Antoinette Bourignon (1616-168o). Zutphen.

37 Cf. Watt (2001).

38 De Baar (2004) 398-404. 
Bourignon, A. 1663. La Parole de Dieu, ou Sa Vie Intérieure. In La Vie de Damlle. Antoinette Bourignon. Ecrite partie par elle-meme, partie par une personne de sa connoissance. 1683. Amsterdam.

- 1668. La Vie Extérieure. In La Vie de Dam ${ }^{\text {lle }}$. Antoinette Bourignon. Ecrite partie par elle-meme, partie par une personne de sa connoissance. 1683. Amsterdam. - 1681. L'Academie des Sçavans Theologiens, 3 volumes. Amsterdam.

Burke, P. 1997. Representations of the Self from Petrarch to Descartes. In R. Porter ed., Rewriting the Self. Histories from the Renaissance to the Present. London, New York. Chevallier, M. 1994. Pierre Poiret (1646-1719). Du protestantisme à la mystique. Geneva. Deblaere, A. 1962. De mystieke schrijfster Maria Petyt (1623-1677). Gent.

Herpoel, S. 1999. A la zaga de Santa Teresa: autobiografias por mandato. Amsterdam.

—. 1994. 'Nosce te ipsum', of: schrijven op bevel in Spanje. Over autobiografieën van vrouwen in de Spaanse zeventiende eeuw. In A. Gelderblom and H. Hendrix eds., De vrouw in de Renaissance. Amsterdam. 42-57.

Lottin, A. 2013. Lille. Citadelle de la Contre-Réforme (1598-1668). 2nd. rev. ed. Villeneuve d'Ascq.

Meijer, M. 1996. In tekst gevat. Inleiding tot een kritiek van representatie. Amsterdam. Merlier, J.R.A. ed. 1976. Het Leven van Maria Petyt (1623-1677). Zutphen.

Monteiro, M. 1996. Geestelijke maagden. Leven tussen klooster en wereld in NoordNederland gedurende de zeventiende eeuw. Hilversum.

Petyt, M. 1683/1684. Het leven vande weerdighe moeder Maria a S.ta Teresia, (alias) Petyt, vanden derden reghel vande Orden der Broederen van Onse L. Vrouwe des Berghs Carmeli, tot Mechelen overleden den 1. November 1677. 4 tt. in 2 voll. Ghent: gedruckt bij de hoirs van Jan vanden Kerchove. (Vilvoorde photogr. reprinted [2002]).

Porteman, K. 1997. Schrijven en geschreven worden. Maria Petyt. In: R. Schenkeveld-van der Dussen et al. eds., Met en zonder lauwerkrans. Schrijvende vrouwen uit de vroegmoderne tijd 1550-1850: Van Anna Bijns tot Elise van Calcar. Amsterdam. 281-88.

Porteman, K. and Smits-Veldt, M.B. 2009.Eennieuwvaderland voor de muzen. Geschiedenis van de Nederlandse literatuur 1560-1700. Amsterdam.

Ranft, P. 1994. A Key to Counter Reformation Women's Activism. The Confessor-Spiritual Director. Journal of Feminist Studies in Religion 10: 7-26.

Teresa of Avila. 1990. The Complete Works of Saint Teresa of Jesus. Transl. and ed. by E. Allison Peers; from the critical edition of Silverio de Santa Teresa. 12th ed. London. Vroede, M. de. 1994. 'Kwezels' en 'Zusters'. De geestelijke dochters in de Zuidelijke Nederlanden, $17^{\text {de }}$ en $18^{\text {de }}$ eeuw. Brussel [Brussels].

Watt, D. 2001. Secretaries of God: Women Prophets in Late Medieval and Early Modern England (1997). Paperback. Cambridge.

Weber, A. 1990. Teresa of Avila and the Rhetoric of Femininity. Princeton. 


\section{PART 2}

The Latin Manuscript about the Dutch War and Its Interpretation 